\title{
Pepsin-Assisted Transglutaminase Modification of Functional Properties of a Protein Isolate Obtained from Industrial Sunflower Meal
}

\author{
Petya Ivanova ${ }^{1}$, Vesela I. Chalova ${ }^{1 *}$, Hristo Kalaydzhiev ${ }^{1}$, \\ Mariana Perifanova-Nemska ${ }^{2}$, Turid Rustad ${ }^{3}$ and Lidia Koleva ${ }^{1}$ \\ ${ }^{1}$ University of Food Technologies, Department of Biochemistry and Molecular Biology, \\ 26 Maritsa Bulv., BG-4002 Plovdiv, Bulgaria \\ ${ }^{2}$ University of Food Technologies, Department of Technology of Tobacco, Sugar, \\ Vegetable and Essential Oils, 26 Maritsa Bulv., BG-4002 Plovdiv, Bulgaria \\ ${ }^{3}$ Norwegian University of Science and Technology, Department of Biotechnology and Food Science, \\ Sem Sælandsvei 6/8, NO-7491 Trondheim, Norway \\ Received: November 15, 2016 \\ Accepted: May 4, 2017
}

\begin{abstract}
Summary
The utilization of industrial sunflower meal to produce protein-rich products for the food industry is an alternative approach for better and more efficient use of this agricultural by-product. Sunflower meal proteins possess specific functional properties, which however need improvement to broaden their potential as supplements for delivering high-quality products for human nutrition. The aim of the study is to evaluate the combined influence of low-degree pepsin hydrolysis and transglutaminase (TG) modification on industrial sunflower meal protein isolate functionality at $\mathrm{pH}=2$ to 10 . Three TG-modified pepsin hydrolysates with the degree of hydrolysis of $0.48,0.71$ and $1.72 \%$ were produced and named TG-PH1, TG-PH2 and TG-PH3, respectively. All three TG-modified pepsin hydrolysates exhibited improved solubility at $\mathrm{pH}$ between 3.5 and 5.5 as the highest was observed of TG-PH3 at protein isoelectric point $(\mathrm{pI}=4.5)$. Sunflower meal protein isolate and TG-modified sunflower meal protein isolate had greater solubility than the three TG-modified hydrolysates at $\mathrm{pH}<3$ and $>7$. Significant improvement of foam making capacity $(\mathrm{p}<0.05)$ was achieved with all three TG-modified pepsin hydrolysates in the entire $\mathrm{pH}$ area studied. Pepsin hydrolysis of the protein isolate with the three degrees of hydrolysis did not improve foam stability. Improved thermal stability was observed with TG-PH3 up to $80^{\circ} \mathrm{C}$ compared to the protein isolate $(\mathrm{pH}=7)$. At $90{ }^{\circ} \mathrm{C}$, TG modification of the protein isolate alone resulted in the highest thermal stability. Pepsin hydrolysis followed by a treatment with TG could be used to produce sunflower protein isolates with improved solubility, foam making capacity and thermal stability for use in the food industry.
\end{abstract}

Key words: industrial sunflower meal, pepsin, protein hydrolysates, transglutaminase modification, functional properties

\footnotetext{
*Corresponding author: Phone: +359 32603 855; Fax: +359 32644 102; E-mail: veselachalova@gmail.com 


\section{Introduction}

Sunflower is an economically important oil-bearing crop which is primarily used for production of vegetable oil. In 2012, sunflower oil production reached 15.22 million tonnes worldwide (1) and was further projected to increase due to enhanced consumer demand for trans-fat-free unsaturated fats (2) and its potential value as a feedstock for biodiesel generation (3). Either for food or technical purposes, the oil extraction results in a substantial quantity of sunflower meal, which may reach up to $30 \%$ of the initial amount of the used sunflower seeds (4). Currently, this by-product is used as a protein source in the feed industry. However, its application in animal nutrition is limited due to high fibre content (5). To avoid adverse performance effect, sunflower meal inclusion in broiler and swine diets should not exceed 16 and $20 \%$, respectively $(4,6)$. The overproduction and accumulation of excessive amounts of unutilized sunflower meal causes higher storage or disposal expenses leading to overall decrease in net profit margin.

The utilization of industrial sunflower meal for generation of protein-rich products for the food industry is an alternative approach for better and more efficient use of this agricultural by-product. Sunflower meal proteins have a high nutritive value. They do not contain antinutritional compounds and exhibit well-balanced amino acid composition with the exception of a low level of lysine (7). Sunflower meal proteins possess specific functional properties, which however need improvement to broaden their potential as supplements for delivering high-quality products for human nutrition $(8,9)$.

Major challenges in preparation of sunflower meal-derived protein products and their subsequent application in the food industry are related to the alteration of protein characteristics due to technological parameters of oil production and sunflower seed pretreatment. Industrial sunflower meal is produced after treatment of sunflower seeds with high temperature and organic solvents which, in most cases, decrease the nutritive value of sunflower meal proteins and reduce their functional properties (10). Enzymatic treatment of plant-derived proteins with pepsin, trypsin or Alcalase ${ }^{\circledR}$ is a common approach aiming at improvement of functional properties (11-13). For example, Martinez et al. (14) improved foaming capacity of sunflower protein by limited enzymatic digestion (degree of hydrolysis $1.5 \%$ ) with Alcalase. Karayannidou et al. (15) reported that limited proteolysis of sunflower protein isolate with trypsin was very efficient in stabilizing emulsions and foam. By using a sequential two-step enzymatic digestion with chymotrypsin and carboxypeptidase, Bautista et al. (16) obtained sunflower protein hydrolysates with decreased allergenicity and a high Fischer ratio.

Transglutaminase (TG) catalyzes the cross-linking of proteins by formation of $\varepsilon-(\gamma$-glutamyl)-lysine bonds (17). TG is predominantly used to alter the functionality of proteins of animal origin and has a wide application in the dairy industry and meat and fish processing (18). However, successful application of TG to alter plant protein functionality for the production of tofu, bread and other wheat products has also been reported $(19,20)$.
Ivanova (9) demonstrated the potential of microbial TG to improve thermal stability and foam making capacity of proteins isolated from industrial sunflower meal. In a later study, it was observed that limited hydrolysis of sunflower meal protein isolate with pepsin facilitated TG reaction and resulted in approx. 4-fold faster polymerization than unhydrolyzed counterpart (21). However, to the best of our knowledge, no information about the effects of preceding enzymatic hydrolysis and cross-linking with TG on the functional properties of industrial sunflower meal protein isolates is available in literature. The aim of the current study is to evaluate the combined influence of low-degree pepsin hydrolysis and TG modification on sunflower protein isolate functionality in a wide $\mathrm{pH}$ range (from 2 to 10). Solubility, thermal stability, foam capacity and stability, and emulsifying activity and stability of three TG-modified pepsin hydrolysates with low degree of hydrolysis $(0.48,0.71$ and $1.72 \%)$ were evaluated.

\section{Materials and Methods}

\section{Materials}

Sunflower meal was obtained from a local company (Biser Oliva, Stara Zagora, Bulgaria). It was produced after thermal treatment of sunflower seeds at $110{ }^{\circ} \mathrm{C}$ followed by oil extraction with hexane at $55{ }^{\circ} \mathrm{C}$. Microbial TG (Activa ${ }^{\circledR} \mathrm{WM}$ ) was kindly provided by Ajinomoto Co., Inc. (Tokyo, Japan) for research purposes. All reagents used in the study were of analytical grade and bought from Sigma-Aldrich (St. Louis, MO, USA).

\section{Preparation of protein isolate}

Proteins were extracted with $10 \% \mathrm{NaCl}(\mathrm{pH}=6)$ and isolated by isoelectric precipitation at $\mathrm{pH}=2.5$ with $6 \mathrm{M}$ $\mathrm{HCl}$ as described by Ivanova et al. (22). The protein precipitate was collected by centrifugation at $1800 \times g$ for 15 min (MPW 251; Medical Instruments, Warsaw, Poland), washed three times with $100 \mathrm{~mL}$ of $\mathrm{HCl}(\mathrm{pH}=2.5)$, dried by lyophilization (Lyovac GT2; Leybold Heraeus, Köln, Germany) and stored for further analyses.

\section{Enzymatic modification of protein isolate}

Protein isolate $(2.0 \%)$ was dissolved in $70 \mathrm{~mL}$ of distilled water and hydrolyzed with pepsin (EC 3.4.23.1; 6 $\mathrm{U} / \mathrm{g}$ protein) at $40{ }^{\circ} \mathrm{C}$ for 15,45 and $120 \mathrm{~min}$. The $\mathrm{pH}$ was maintained at 1.8 by adding $0.1 \mathrm{M} \mathrm{HCl}$ when needed. The reaction was stopped by increasing the $\mathrm{pH}$ to 7.5 with $1 \mathrm{M}$ $\mathrm{NaOH}$, after which TG (EC 2.3.2.13; $5 \mathrm{U} / \mathrm{g}$ protein) was added to the reaction mixture. TG modification occurred for $2 \mathrm{~h}$ at $40{ }^{\circ} \mathrm{C}$. Inactivation of TG was achieved by adding $1 \%$ N-ethylmaleimide (23).

Degree of hydrolysis of pepsin proteolysates was evaluated after removal of unhydrolyzed protein by precipitation with $10 \%$ trichloroacetic acid (final concentration) and subsequent centrifugation for $20 \mathrm{~min}$ at $1800 \times \mathrm{g}$ (MPW 251; Medical Instruments). It was calculated by the following equation:

$$
\mathrm{DH}=\frac{\gamma_{\alpha-\mathrm{N}}}{\gamma_{\mathrm{N}}} \cdot 100
$$


where DH is the degree of hydrolysis (\%), $\gamma_{\alpha-\mathrm{N}}$ is the concentration of soluble $\alpha$-amino nitrogen in the supernatant $(\mathrm{mg} / \mathrm{mL})$, and $\gamma_{\mathrm{N}}$ is the concentration of total nitrogen in the sample used in the assay $(\mathrm{mg} / \mathrm{mL})$. The $\alpha$-amino nitrogen in the supernatant was estimated by ninhydrin method and glycine was used to generate a standard curve (24). Total nitrogen was determined by Kjeldahl's method (25).

\section{Solubility}

Protein solubility was determined as described by González-Pérez and Vereijken (7) with some modifications. Proteins were dispersed in water to a final concentration of $4 \mathrm{mg} / \mathrm{mL}$. The $\mathrm{pH}$ values were varied in the range from 2.0 to 8.5 with increments of 0.5 by using either $\mathrm{NaOH}$ or $\mathrm{HCl}$. After $2 \mathrm{~h}$ at room temperature, the suspension was centrifuged for $15 \mathrm{~min}$ at $1800 \times g$ (MPW 251; Medical Instruments). Soluble protein in the supernatant was evaluated by biuret method (26). Bovine serum albumin was used for generation of a standard curve. The protein solubility was calculated by the following equation:

$$
\mathrm{PS}=\frac{m_{\mathrm{ps}}}{m_{\mathrm{tp}}} \cdot 100
$$

where PS is protein solubility (\%), $m_{\mathrm{ps}}$ is the mass of soluble protein in the supernatant (mg), and $m_{\mathrm{tp}}$ is the mass of total protein in the used sample (mg).

\section{Foam capacity and stability}

Foam capacity and stability were determined as described by Sze-Tao and Sathe (27) with some modifications. An aliquot of $20 \mathrm{~mL}$ of protein solution $(0.5 \mathrm{mg} / \mathrm{mL})$ was whipped for $70 \mathrm{~s}$ in a graduated cylinder as described by Ivanova et al. (28). Foam capacity was determined by volume increase immediately after whipping and was calculated by the formula:

$$
\mathrm{FC}=\frac{\left(V_{2}-V_{1}\right)}{V_{1}} \cdot 100
$$

where FC is foam capacity (\%), $V_{1}$ is the volume of protein solution before whipping $(\mathrm{mL})$ and $V_{2}$ is the volume of the solution after whipping $(\mathrm{mL})$. The influence of $\mathrm{pH}$ on foaming properties was tested by varying the $\mathrm{pH}$ from 2 to 10 with increments of 2 units using $\mathrm{NaOH}$ or $\mathrm{HCl}$. The foam stability was defined as the volume of the foam that remained after $60 \mathrm{~min}$ at room temperature $\left(23^{\circ} \mathrm{C}\right)$ and was calculated by the following equation:

$$
\mathrm{FS}=\frac{V_{\mathrm{t} 60}}{V_{\mathrm{t} 0}} \cdot 100
$$

where FS is foam stability (\%), $V_{\mathrm{t} 60}$ is the volume of the foam that remained after $60 \mathrm{~min}(\mathrm{~mL})$, and $V_{\mathrm{t} 0}$ is the volume of the foam immediately after whipping $(\mathrm{mL})$.

\section{Emulsifying properties}

Emulsifying activity and emulsion stability were determined as described by Neto et al. (29). A volume of 5 $\mathrm{mL}$ of protein solution $(0.5 \mathrm{mg} / \mathrm{mL})$ was homogenized with $5 \mathrm{~mL}$ of food-grade sunflower oil for $60 \mathrm{~s}$ at $1000 \mathrm{rpm}$ by using a homogenizer (T18 Ultra Turrax Basic; IKA ${ }^{\circledR}$ -Werke GmbH \& Co.KG, Staufen, Germany). The emul- sion was centrifuged for $5 \mathrm{~min}$ at $1800 \times g$ (MPW 251; Medical Instruments) and the volume of the emulsified layer was recorded (28). The emulsifying activity was calculated by the following equation:

$$
\mathrm{EA}=\frac{V_{\mathrm{el}}}{V_{\mathrm{T}}} \cdot 100
$$

where EA is emulsifying activity (\%), $V_{\mathrm{el}}$ is the volume of the emulsified layer $(\mathrm{mL})$, and $V_{\mathrm{T}}$ is the volume of the total content of the tube $(\mathrm{mL})$.

Emulsion stability was established after heating at 80 ${ }^{\circ} \mathrm{C}$ in a water bath (WNB 29; Memmert GmbH+Co.KG, Schwabach, Germany) for $30 \mathrm{~min}$. The emulsion was cooled down to room temperature $\left(23^{\circ} \mathrm{C}\right)$ and centrifuged at $1800 \times g$ for 5 min (MPW 251; Medical Instruments). Emulsion stability was calculated by the following equation:

$$
\mathrm{ES}=\frac{V_{\mathrm{el} 30}}{V_{\mathrm{el} 0}} \cdot 100
$$

where ES is the emulsion stability (\%), $V_{\mathrm{el} 30}$ is the volume of emulsified layer after $30 \mathrm{~min}$ of heating $(\mathrm{mL})$, and $V_{\mathrm{el} 0}$ is the volume of the emulsified layer before heating $(\mathrm{mL})$. $\mathrm{NaOH}$ or $\mathrm{HCl}$ was added to protein solutions to modulate the $\mathrm{pH}$ from 2 to 10 with increments of 2 where appropriate.

\section{Thermal stability}

Thermal stability was determined as described by Kato et al. (30). Aliquots of $5 \mathrm{~mL}$ of protein solutions (2 $\mathrm{mg} / \mathrm{mL}$ ) were adjusted to either $\mathrm{pH}=7.0$ or 8.0 and were heated for $20 \mathrm{~min}$ at temperatures varying from 50 to $90{ }^{\circ} \mathrm{C}$ with increments of $10^{\circ} \mathrm{C}$. After cooling to room temperature $\left(23^{\circ} \mathrm{C}\right)$, the turbidity of the solutions was measured at $\lambda=500 \mathrm{~nm}$ (Spekol 11; Carl Zeiss Jena, Jena, Germany). Distilled water was used as a control. Thermal stability was calculated by the following equation:

$$
\mathrm{TS}=\frac{\left(S_{\mathrm{Ti}}-S_{\mathrm{RT}}\right)}{S_{\mathrm{RT}}} \cdot 100
$$

where TS is thermal stability (\%), $S_{\mathrm{Ti}}$ is the sample turbidity at a specific temperature, and $S_{\mathrm{RT}}$ is the sample turbidity at room temperature $\left(23^{\circ} \mathrm{C}\right)$.

\section{Statistical analysis}

Data are presented as mean values of at least three independent experiments \pm standard deviation (S.D.). Statistical evaluation was performed by one-way analysis of variance (ANOVA) using Statgraphics Centurion statistical program (v. XVI; StatPoint Technologies, Inc., Warrenton, VA, USA). Mean differences were established by Fisher's least significant difference test for paired comparison with a significance level at $\alpha=0.05$.

\section{Results and Discussion}

To evaluate a combined influence of pepsin and transglutaminase (TG) enzymatic modifications on protein functionality, sunflower meal protein isolate was initially hydrolyzed with pepsin for 15, 45 and $120 \mathrm{~min}$. Respective hydrolysates, $\mathrm{PH} 1, \mathrm{PH} 2$ and $\mathrm{PH} 3$, were characterized with low degree of hydrolysis $(\mathrm{DH})$, namely $0.48,0.71$ 


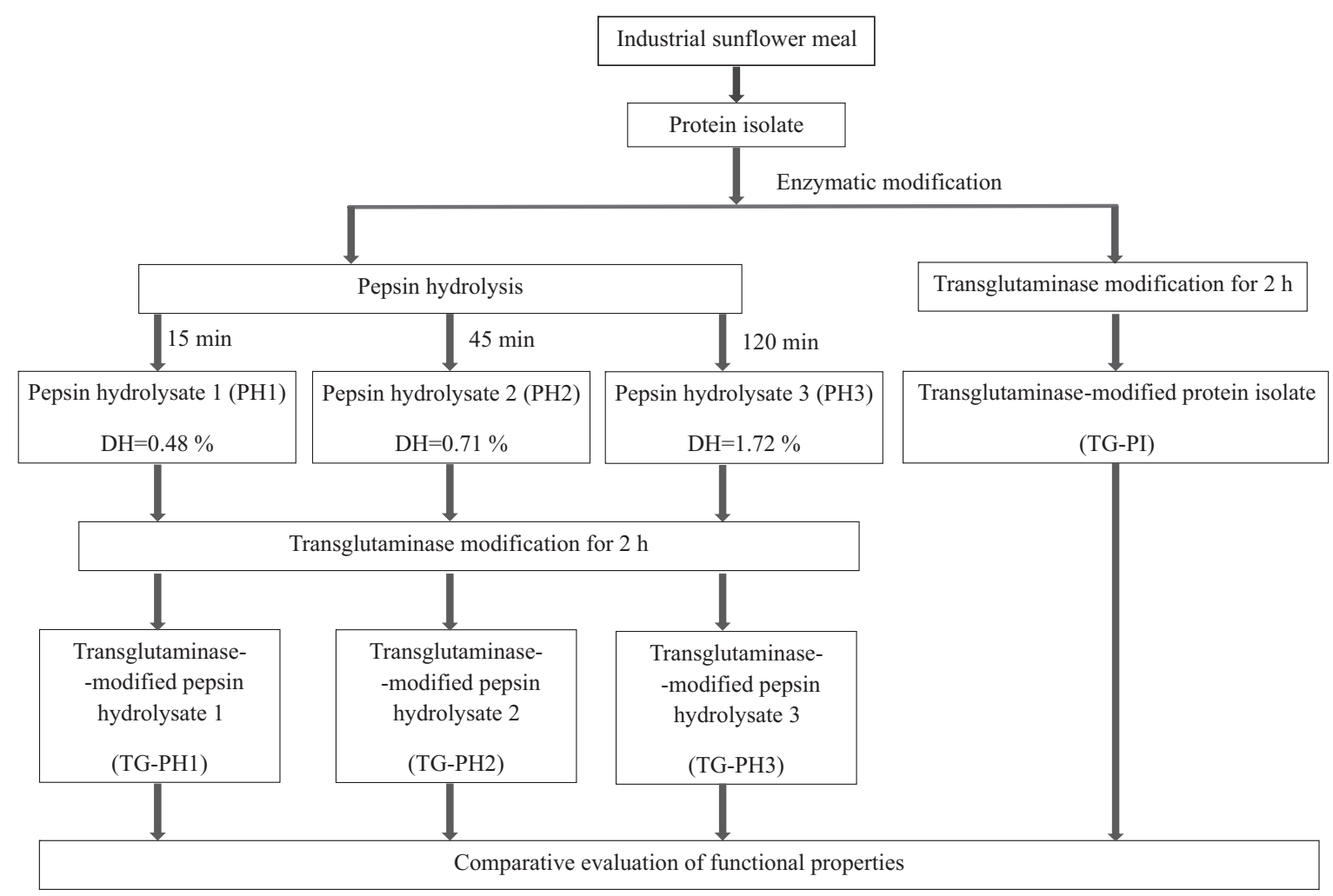

Fig. 1. Flow chart for comparative evaluation of functional properties of sunflower meal protein isolate enzymatically modified with pepsin and transglutaminase. $\mathrm{DH}=$ degree of hydrolysis

and $1.72 \%$. The following treatment with TG resulted in the preparation of TG-modified pepsin hydrolysates, named TG-PH1, TG-PH2 and TG-PH3, respectively. Their functional properties were evaluated and compared to the functional properties of TG-modified protein isolate (TG-PI) and untreated protein isolate. The design of the study is schematically presented in Fig. 1.

\section{Solubility of sunflower protein isolates}

Good solubility is usually required for a protein to have good functional properties (31). In our study, improved solubility at $\mathrm{pH}=3.5-5.5$ was achieved with the three TG-modified pepsin hydrolysates and the most pronounced effect was observed with TG-PH3 (Fig. 2). Approximately 3- and 3.5-fold increase in TG-PH3 solubility was observed compared to TG-PH2 and TG-PH1, respectively. Compared to protein isolate and TG-modified protein isolate, the solubility of TG-PH3 increased more than 15-fold at $\mathrm{pH}=4.5$. As previously determined in our laboratory, the protein isolate was rich in sulfur-containing amino acids (amino acid score $99.14 \%$ ) (32) and, therefore, could serve as a food additive to balance these specific amino acids in human diets if appropriate solubility is provided (33). Limited pepsin hydrolysis of protein isolate combined with TG treatment resulted in structures with good solubility at $\mathrm{pH}=4.0-6.0$.

The results implied that limited hydrolysis of the protein with pepsin decreased the influence of $\mathrm{pH}$ on protein solubility at the isoelectric point ( $\mathrm{pI}=4.5)$. Apparently, pepsin hydrolysis of protein isolate is a prerequisite step for the following TG modification to obtain more hydrophilic structures with improved solubility. In a previous study, the hydrolysis of sunflower meal protein isolate with pepsin followed by TG treatment resulted in the increase of the amount of $200-\mathrm{kDa}$ protein fractions at the expense of fractions with higher molecular mass (21). Our results are in agreement with the results of Walsh et al. (34) showing increased solubility of TG-cross-linked products of soy protein isolate Alcalase ${ }^{\mathrm{TM}}$ hydrolysates. Flanagan and FitzGerald (35) also observed improved solubility of sodium caseinate at around $\mathrm{pH}=4.6$ after combined enzymatic treatments with Protamex and TG compared

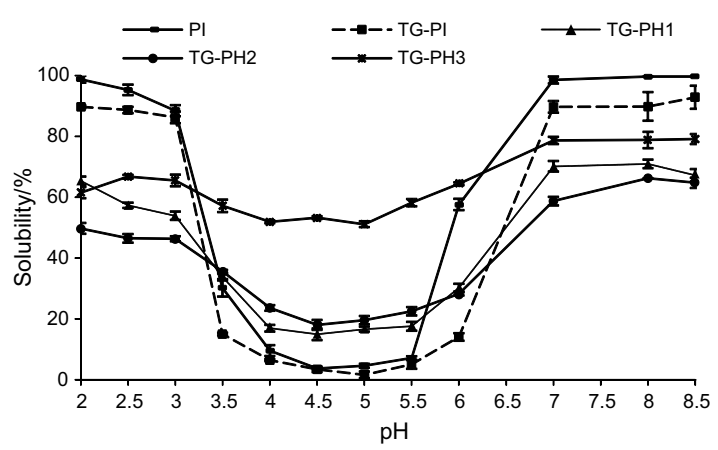

Fig. 2. Influence of $\mathrm{pH}$ on the solubility of sunflower protein isolate (PI) and sunflower protein pepsin digests after treatment with transglutaminase (TG). TG-PI=TG-modified protein isolate, TG-PH1, 2 and 3=TG-modified pepsin hydrolysates with degree of hydrolysis (DH) of $0.48,0.71$ and $1.72 \%$, respectively 
to either TG-modified protein or sodium caseinate hydrolysate alone. Improved solubility of enzymatic digests of gluten by chymotrypsin, papain, pronase and pepsin followed by a TG treatment over a wide $\mathrm{pH}$ range was reported by Babiker et al. (36).

In general, protein solubility depends on molecular mass, overall charge and surface hydrophobicity. Higher solubility can be expected of proteins with lower molecular mass, higher molecular charge and low surface hydrophobicity. According to Hassan et al. (37), TG treatment of proteins decreases surface hydrophobicity due to partial deamination of glutamine and asparagine. In our study, the decrease in surface hydrophobicity was most probably compensated by the increase in molecular mass after protein polymerization and the solubility pattern of TG-PI followed the one of untreated protein isolate (Fig. 2). Protein isolate and TG-modified protein isolate, however, expressed greater solubility than TG-PH1, TG-PH2 and TG-PH3 at $\mathrm{pH} \leq 3$ and $\geq 7$, which determines their better practical application in formulations of food with highly acidic, neutral or slightly alkaline $\mathrm{pH}$.

\section{Alteration of foam capacity and stability by enzymatic modification}

Foam capacity followed the overall trend observed for protein solubility. Protein isolate expressed the lowest foam making capacity at around protein $\mathrm{pI}(\mathrm{pH}=4$ and 6), which is related to low molecular charge and the formation of high-molecular-mass aggregates (Fig. 3). The highest foam making capacity of protein isolate, observed at $\mathrm{pH}=2(47.7 \%)$, is probably due to dissociation of sunflower protein globulins to monomers, thus contributing to increase in foam volume (38). The modification of protein isolate with TG slightly increased the foam making capacity at $\mathrm{pH}=4$ and 6 which, however, did not exceed $40.0 \%$. Significant improvement $(\mathrm{p}<0.05)$ was achieved with all three TG-modified pepsin hydrolysates (TG-PH1, TG-PH2, TG-PH3), which resulted in foam making capacity varying from 52 to $66 \%$ in the entire $\mathrm{pH}$ range studied. Although no direct comparison can be made because of differences in the used substrates and evaluation meth-

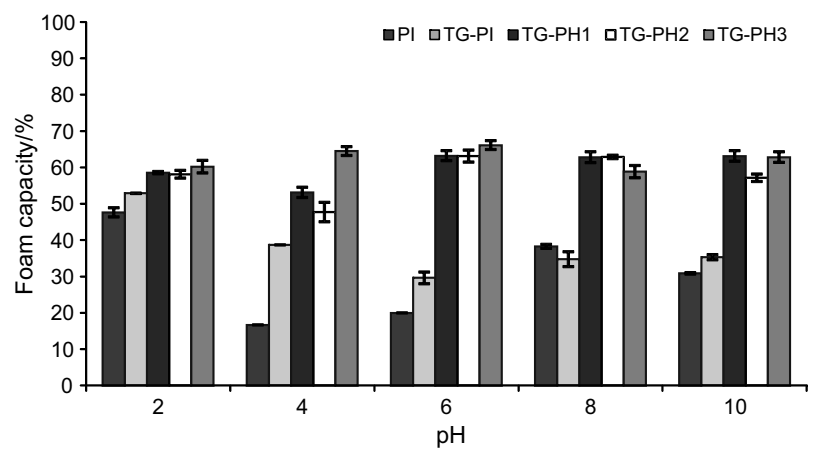

Fig. 3. Foam capacity at different $\mathrm{pH}$ values of sunflower protein isolate (PI) and sunflower protein pepsin digests after treatment with transglutaminase (TG). TG-PI=TG-modified protein isolate, TG-PH1, 2 and 3=TG-modified pepsin hydrolysates with degree of hydrolysis (DH) of $0.48,0.71$ and $1.72 \%$, respectively ods, similar observations were reported by Babiker (39). The foam capacity of the soy protein and chymotrypsin-based soy protein hydrolysate after polymerization with TG increased from 500 to $590 \mu \mathrm{v} / \mathrm{cm}$ respectively, as measured by electrical conductivity. In an earlier study, Babiker et al. (36) also established an improvement of foaming properties after TG polymerization of gluten hydrolysates prepared with chymotrypsin, papain, pronase and pepsin. Flanagan and FitzGerald (40) reported $1433 \%$ foam expansion of the sodium caseinate product obtained after hydrolysis with Bacillus proteinase and TG polymerization.

In contrast to foam making capacity, pepsin hydrolysis of the protein isolate with three degrees of hydrolysis $(0.48,0.71$ and $1.72 \%)$ did not improve the foam stability (Fig. 4). In fact, the highest degree of hydrolysis (1.72\%) gave the lowest foam stability at $\mathrm{pH}=6$. Inverse relationship between the degree of hydrolysis and foam stability of protein hydrolysates was attributed to the decrease in the amount of larger protein component required for foam stabilization (41). A similar trend was observed by Kong at al. (42) and Wouters et al. (43) while studying wheat gluten hydrolysates, and by Guan et al. (44) and Larré et al. (45) for hydrolysates of oat bran protein concentrate and rapeseed protein isolate, respectively.

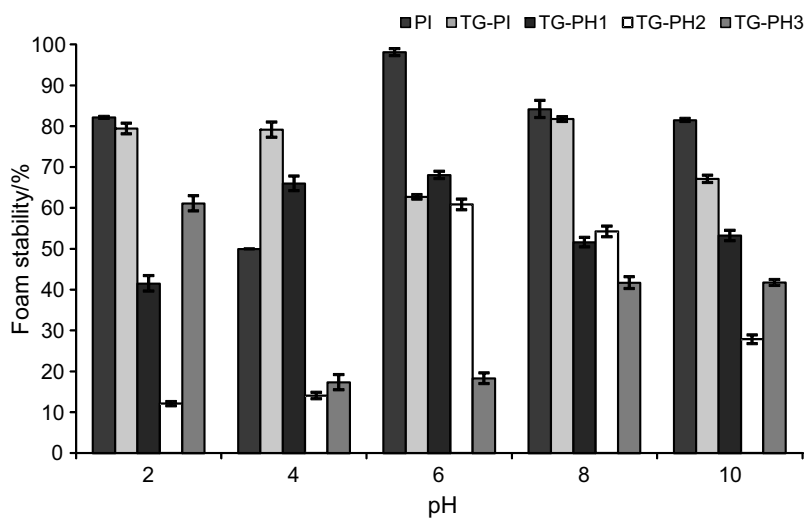

Fig. 4. Foam stability at different $\mathrm{pH}$ values of sunflower protein isolate (PI) and sunflower protein pepsin digests after treatment with transglutaminase (TG). TG-PI=TG-modified protein isolate, TG-PH1, 2 and 3=TG-modified pepsin hydrolysates with degree of hydrolysis (DH) of $0.48,0.71$ and $1.72 \%$, respectively

Our results were not in agreement with the results reported by Babiker (39), who observed increased foam stability of the chymotrypsin-digested soy protein polymerized with bacterial TG. This may be due to differences in the substrates used in the study as well as differences of the protein profiles of the hydrolysates obtained with pepsin and chymotrypsin. Jung et al. (46) revealed that porcine placenta was barely hydrolyzed by pepsin, resulting in peptides with molecular mass $(M)$ greater than $7 \mathrm{kDa}$, while chymotrypsin produced peptides with broad ranges of $M$, from 1 to $20 \mathrm{kDa}$. Although high molecular complexes are necessary for stabilization of foam, excessive aggregation may impede the formation of a viscoelastic protein film at the air-water boundary (47). 


\section{Influence of enzymatic treatment on emulsifying properties}

Overall, no statistically significant improvement of the emulsifying properties of enzymatically modified sunflower protein isolate was achieved compared to the unmodified counterpart (Tables 1 and 2). Chobert et al. (48) suggested that low molecular mass peptides may have too low amphiphilic capacity to exhibit technologically satisfying emulsifying properties. Although small-size peptides are advantageous in the migration and interface absorption, they seem inefficient for stabilizing emulsions most probably due to improper unfolding and reorientation at the interface (49). Reductions in emulsifying properties of enzymatic hydrolysates of blends of groundnut flour and sorghum meal and defatted groundnut flour were reported by Ahmed and Ramanatham (50) and Subba Rau and Srinivasan (51) respectively. Our results agreed with Hu et al. (52), who did not observe any effect of TG on emulsifying activity of peanut protein isolate except at $\mathrm{pH}=4$ when TG-modified protein isolate exhibited the highest emulsifying activity $(53.8 \%$, Table 1$)$.

\section{Influence of temperature on protein stability}

Thermal stability was studied at $\mathrm{pH}=7$ and 8 because of the relatively high solubility of all protein isolates at these $\mathrm{pH}$ values (Fig. 2) and their potential practical application in food systems. Reaction $\mathrm{pH}$ is an important factor influencing protein heat stability since it affects protein charge, conformation and sulfhydryl reactivity upon aggregation (53). $\mathrm{Up}$ to $80{ }^{\circ} \mathrm{C}(\mathrm{pH}=7)$, TG-PH3 exhibited lower increases in turbidity and, therefore, better thermal stability than that of protein isolate (Table 3). The thermal stability of TG-PH3 was better at 50 and $60^{\circ} \mathrm{C}$ than of TG-modified protein isolate. Babiker (39) reported improved thermal resistance of chymotrypsin-digested soy protein up to $60^{\circ} \mathrm{C}$ after TG treatment. The lower-degree pepsin hydrolyses $(0.48$ and $0.71 \%)$ followed by TG polymerization (TG-PH1 and TG-PH2) resulted in reduced thermal stability compared to unmodified protein isolate at all studied temperatures. The reason may be the formation of less hydrophilic structures at $\mathrm{pH}=7$ and 8 (Fig. 2), which in general, leads to a decrease in protein stability (54). Similar trends in thermal stability of TG-modified sunflower protein isolates, predigested with pepsin, were also observed at $\mathrm{pH}=8$ (Table 4 ).

Improvement of heat stability after TG modification of the sunflower protein isolate alone compared to unmodified protein isolate was observed only at higher thermal treatments $\left(70,80\right.$ and $\left.90^{\circ} \mathrm{C}\right)$ at $\mathrm{pH}=7$ (Table 3). Decreases in turbidity at $90^{\circ} \mathrm{C}$ of pigeon pea and hyacinth bean protein isolates after TG treatment compared to the native

Table 1. Emulsifying activity of sunflower protein isolate (PI) and sunflower protein pepsin digests after treatment with transglutaminase (TG) at different $\mathrm{pH}$ values

\begin{tabular}{llcccc}
\hline & \multicolumn{4}{c}{ Emulsifying activity/\% } \\
\cline { 2 - 5 } & \multicolumn{5}{c}{$\mathrm{pH}$} \\
\cline { 2 - 5 } & 2 & 4 & 6 & 8 & 10 \\
\hline PI & $(52.9 \pm 2.5)^{\mathrm{aA}}$ & $(44.7 \pm 1.7)^{\mathrm{bB}}$ & $(53.6 \pm 3.6)^{\mathrm{aA}}$ & $(54.5 \pm 3.4)^{\mathrm{aA}}$ & $(55.7 \pm 3.46)^{\mathrm{aA}}$ \\
TG-PI & $(50.6 \pm 0.0)^{\mathrm{dAB}}$ & $(53.8 \pm 0.0)^{\mathrm{bCA}}$ & $(55.5 \pm 0.4)^{\mathrm{aA}}$ & $(53.3 \pm 0.0)^{\mathrm{cAB}}$ & $(54.2 \pm 0.42)^{\mathrm{bAB}}$ \\
TG-PH1 & $(51.6 \pm 2.3)^{\mathrm{bAB}}$ & $(46.6 \pm 0.0)^{\mathrm{CB}}$ & $(45.3 \pm 0.0)^{\mathrm{cB}}$ & $(46.0 \pm 0.9)^{\mathrm{CC}}$ & $(56.2 \pm 0.00)^{\mathrm{aA}}$ \\
TG-PH2 & $(44.7 \pm 2.6)^{\mathrm{bB}}$ & $(44.7 \pm 2.6)^{\mathrm{bB}}$ & $(46.6 \pm 0.0)^{\mathrm{abB}}$ & $(50.0 \pm 0.0)^{\mathrm{aBC}}$ & $(50.0 \pm 0.00)^{\mathrm{aBC}}$ \\
TG-PH3 & $(50.0 \pm 4.7)^{\mathrm{aAB}}$ & $(9.7 \pm 1.0)^{\mathrm{bC}}$ & $(48.3 \pm 2.3)^{\mathrm{aB}}$ & $(50.0 \pm 0.0)^{\mathrm{aBC}}$ & $(48.5 \pm 2.09)^{\mathrm{aC}}$ \\
\hline
\end{tabular}

Mean values in a row with the same lower case letter do not differ significantly $(\mathrm{p} \geq 0.05)$.

Mean values in a column with the same capital letter do not differ significantly $(p \geq 0.05)$.

TG-PI=TG-modified protein isolate, TG-PH1, 2 and 3=TG-modified pepsin hydrolysates with degree of hydrolysis (DH) of $0.48,0.71$ and $1.72 \%$, respectively

Table 2. Emulsifying stability of sunflower protein isolate (PI) and sunflower protein pepsin digests after treatment with transglutaminase (TG) at different $\mathrm{pH}$ values

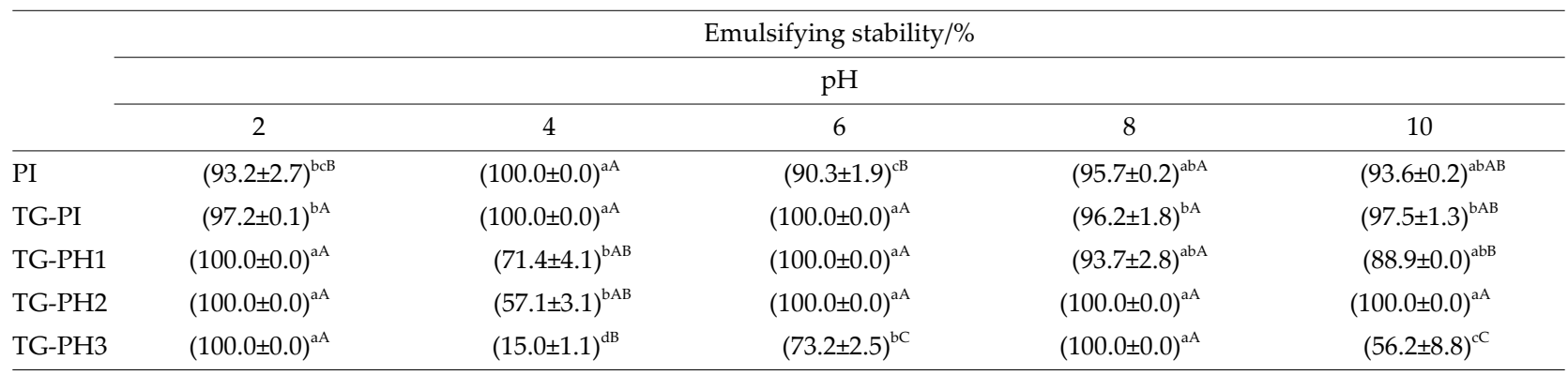

Mean values in a row with the same lower case letter do not differ significantly $(p \geq 0.05)$.

Mean values in a column with the same capital letter do not differ significantly $(\mathrm{p} \geq 0.05)$.

TG-PI=TG-modified protein isolate, TG-PH1, 2 and 3=TG-modified pepsin hydrolysates with degree of hydrolysis (DH) of $0.48,0.71$ and $1.72 \%$, respectively 
Table 3. Thermal stability of sunflower protein isolate (PI) and sunflower protein pepsin digests after treatment with transglutaminase (TG) at $\mathrm{pH}=7$

\begin{tabular}{|c|c|c|c|c|c|}
\hline \multirow{2}{*}{ Temperature $/{ }^{\circ} \mathrm{C}$} & \multicolumn{5}{|c|}{ Turbidity/\%* } \\
\hline & PI & TG-PI & TG-PH1 & TG-PH2 & TG-PH3 \\
\hline 50 & $(4.2 \pm 1.9)^{\mathrm{b}}$ & $(4.2 \pm 0.3)^{\mathrm{b}}$ & $(4.7 \pm 0.0)^{\mathrm{b}}$ & $(43.9 \pm 3.2)^{\mathrm{a}}$ & $(0.8 \pm 1.2)^{\mathrm{c}}$ \\
\hline 60 & $(5.4 \pm 0.2)^{c}$ & $(4.4 \pm 1.6)^{c}$ & $(18.3 \pm 2.3)^{\mathrm{b}}$ & $(48.1 \pm 2.7)^{\mathrm{a}}$ & $(1.7 \pm 2.4)^{\mathrm{d}}$ \\
\hline 70 & $(9.9 \pm 0.5)^{c}$ & $(4.9 \pm 0.2)^{\mathrm{d}}$ & $(28.2 \pm 7.2)^{\mathrm{b}}$ & $(72.5 \pm 0.7)^{\mathrm{a}}$ & $(4.8 \pm 6.8)^{\mathrm{d}}$ \\
\hline 80 & $(15.2 \pm 0.8)^{c}$ & $(6.9 \pm 2.5)^{\mathrm{d}}$ & $(39.9 \pm 6.3)^{b}$ & $(73.5 \pm 0.7)^{\mathrm{a}}$ & $(6.6 \pm 0.0)^{d}$ \\
\hline 90 & $(18.1 \pm 0.8)^{\mathrm{c}}$ & $(10.3 \pm 0.2)^{\mathrm{d}}$ & $(45.9 \pm 9.2)^{\mathrm{b}}$ & $(75.0 \pm 0.0)^{\mathrm{a}}$ & $(17.0 \pm 0.8)^{\mathrm{c}}$ \\
\hline
\end{tabular}

*Thermal stability was evaluated as the increase of sample turbidity expressed in percentage.

Mean values in a row with the same lower case letter do not differ significantly ( $\mathrm{p} \geq 0.05)$.

TG-PI=TG-modified protein isolate, TG-PH1, 2 and 3=TG-modified pepsin hydrolysates with degree of hydrolysis (DH) of $0.48,0.71$ and $1.72 \%$, respectively

Table 4. Thermal stability of sunflower protein isolate (PI) and sunflower protein pepsin digests after treatment with transglutaminase $(\mathrm{TG})$ at $\mathrm{pH}=8$

\begin{tabular}{|c|c|c|c|c|c|}
\hline \multirow{2}{*}{ Temperature $/{ }^{\circ} \mathrm{C}$} & \multicolumn{5}{|c|}{ Turbidity/\%* } \\
\hline & PI & TG-PI & TG-PH1 & TG-PH2 & TG-PH3 \\
\hline 50 & $(4.7 \pm 0.3)^{\mathrm{b}}$ & $(4.9 \pm 1.4)^{\mathrm{b}}$ & $(15.8 \pm 1.5)^{\mathrm{a}}$ & $(14.0 \pm 3.6)^{\mathrm{a}}$ & $(2.3 \pm 4.7)^{\mathrm{c}}$ \\
\hline 60 & $(7.7 \pm 0.0)^{\mathrm{bc}}$ & $(6.1 \pm 1.4)^{\mathrm{bc}}$ & $(16.6 \pm 8.6)^{\mathrm{ab}}$ & $(24.2 \pm 3.1)^{\mathrm{a}}$ & $(2.3 \pm 0.0)^{\mathrm{d}}$ \\
\hline 70 & $(11.7 \pm 0.3)^{\mathrm{b}}$ & $(6.7 \pm 1.1)^{c}$ & $(22.5 \pm 3.1)^{\mathrm{a}}$ & $(26.3 \pm 3.9)^{a}$ & $(4.35 \pm 6.1)^{c}$ \\
\hline 80 & $(13.9 \pm 0.0)^{\mathrm{b}}$ & $(9.3 \pm 0.0)^{\mathrm{b}}$ & $(36.7 \pm 6.6)^{\mathrm{a}}$ & $(31.5 \pm 1.7)^{\mathrm{a}}$ & $(11.5 \pm 1.3)^{\mathrm{b}}$ \\
\hline 90 & $(20.9 \pm 3.7)^{\mathrm{cd}}$ & $(13.1 \pm 0.7)^{\mathrm{d}}$ & $(55.3 \pm 11.9)^{\mathrm{a}}$ & $(41.2 \pm 4.3)^{\mathrm{ab}}$ & $(28.8 \pm 1.7)^{\mathrm{bc}}$ \\
\hline
\end{tabular}

*Thermal stability was evaluated as the increase of sample turbidity expressed in percentage.

Mean values in a row with the same lower case letter do not differ significantly $(\mathrm{p} \geq 0.05)$.

TG-PI=TG-modified protein isolate, TG-PH1, 2 and 3=TG-modified pepsin hydrolysates with degree of hydrolysis (DH) of $0.48,0.71$

and $1.72 \%$, respectively

proteins were observed by Ali et al. (55). According to Siu et al. (56) and O'Sullivan et al. (57), elevated temperatures denature proteins and facilitate TG cross-linking to form aggregates with more compact and heat-stable structures. Ryan et al. (53) reported that $10{ }^{\circ} \mathrm{C}$ difference in heating substantially influenced the degree of polymerization as the maximum level could be reached in $10 \mathrm{~min}$ at $85^{\circ} \mathrm{C}$ (neutral $\mathrm{pH}$ ), while up to $8 \mathrm{~h}$ may be needed for aggregate formation at $70{ }^{\circ} \mathrm{C}$ due to slower denaturation and diffusion rates. Most probably, neutral $\mathrm{pH}$ additionally contributes to the increased heat resistance of the protein aggregates via formation of disulfide bonds, which are diminished at the expense of noncovalent associations maintaining the aggregates at higher $\mathrm{pH}$ values (58). In our study, at $\mathrm{pH}=8$ no statistically significant differences in thermal stability between TG-modified protein isolate and protein isolate were established (Table 4). Thermal treatment is a common approach in food processing, and knowledge on thermal stability of the protein isolates would facilitate their potential application as food ingredients.

\section{Conclusions}

Major challenges in preparation of sunflower meal-derived protein products and their application in the food industry are related to protein characteristics and changes due to processing parameters during oil production. This study demonstrated the application of low-degree pepsin hydrolysis combined with transglutaminase (TG) treatment for the improvement of specific functional properties of a protein isolate prepared from industrial sunflower meal. The results implied that hydrolysis of the protein with pepsin decreased the influence of $\mathrm{pH}$ on protein solubility at isoelectric point ( $\mathrm{pI}=4.5$ ). If greater solubility at $\mathrm{pH}<3$ and $>7$ is needed, enzymatic modification of protein isolate should be avoided. Modification of protein isolate with TG could be useful in the improvement of foam making capacity at $\mathrm{pH}=4$ and 6 . The effect could be enhanced by a preceding pepsin hydrolysis, as evidenced by foam making capacity of TG-PH1, TG-PH2 and TG-PH3, which remained between 52 and $66 \%$ in the entire studied $\mathrm{pH}$ range. Improved heat resistance of protein isolate at the lower range of temperatures studied (up to $80{ }^{\circ} \mathrm{C}, \mathrm{pH}=7$ ) could be achieved by pepsin hydrolysis of protein isolate to $\mathrm{DH}$ of $1.72 \%$ and consequent TG treatment (TG-PH3), while at the higher temperatures (80 and $\left.90{ }^{\circ} \mathrm{C}\right)$, TG modification alone is sufficient for improvement of this characteristic. Data obained in this study could be helpful for production of sunflower protein isolates with desired functional properties.

\section{References}

1. FAOSTAT. Rome, Italy: Food and Agriculture Organization of the United Nations, Statistics Division (FAO); 2013. Available from: http://www.fao.org/faostat/en/\#home. 
2. Wildermuth SR, Young EE, Were LM. Chlorogenic acid oxidation and its reaction with sunflower proteins to form green-colored complexes. Compr Rev Food Sci Food Saf. 2016; 15:829-43. https://doi.org/10.1111/1541-4337.12213

3. Adhikari S, Illukpitiya P. Utilization of oilseed crops for onfarm energy security. J Technol Innov Renew Energy. 2015;4: 113-9.

https://doi.org/10.6000/1929-6002.2015.04.04.1

4. Carellos DC, Lima JAF, Fialho ET, de Freitas RTF, Silva HO, Branco PAC, et al. Evaluation of sunflower meal on growth and carcass traits of finishing pigs. Ciênc Agrotec. 2005;29: 208-15.

https://doi.org/10.1590/S1413-70542005000100026

5. de Araújo WAG, Albino LFT, Rostagno HS, Hannas MI, Pessoa GBS, Messias RKG, et al. Sunflower meal and enzyme supplementation of the diet of 21- to 42-d-old broilers. Rev Bras Cienc Avic. 2014;16:17-24. https://doi.org/10.1590/1516-635x160217-24

6. Tavernari FC, Albino LFT, Morata RL, Dutra Júnior WM, Rostagno HS, Viana MTS. Inclusion of sunflower meal, with or without enzyme supplementation, in broiler diets. Rev Bras Cienc Avic. 2008;10:233-8. https://doi.org/10.1590/S1516-635X2008000400007

7. González-Pérez S, Vereijken JM. Sunflower proteins: overview of their physicochemical, structural and functional properties. J Sci Food Agric. 2007;87:2173-91. https://doi.org/10.1002/jsfa.2971

8. Brückner J, Mieth G, Dabrowski K, Gwiazda S, Rutkowski A. Functional properties of sunflower protein isolates in a meat model system. Nahrung. 1982;26:457-63. https://doi.org/10.1002/food.19820260509

9. Ivanova P. Production, characterization and enzymatic modification of protein isolates from sunflower meal [PhD Thesis]. Plovdiv, Bulgaria: University of Food Technologies; 2014 (in Bulgarian).

10. Moure A, Sineiro J, Dominguez H, Parajó JC. Functionality of oilseed protein products: a review. Food Res Int. 2006;39: 945-63. https://doi.org/10.1016/j.foodres.2006.07.002

11. Vioque J, Sánchez-Vioque R, Clemente A, Pedroche J, Millán F. Partially hydrolyzed rapeseed protein isolate with improved functional properties. J Am Oil Chem Soc. 2000;77: 447-50. https://doi.org/10.1007/s11746-000-0072-y

12. McCarthy AL, O'Callaghan YC, O'Brien NM. Protein hydrolysates from agricultural crops - bioactivity and potential for functional food development. Agriculture. 2013;3:112-30. https://doi.org/10.3390/agriculture3010112

13. Polanco-Lugo E, Dávila-Ortiz G, Betancur-Ancona DA, Chel-Guerrero LA. Effects of sequential enzymatic hydrolysis on structural, bioactive and functional properties of Phaseolus lunatus protein isolate. Food Sci Technol-Campinas. 2014;34: $441-8$.

https://doi.org/10.1590/1678-457x.6349

14. Martinez KD, Baeza RI, Millán F, Pilosof AMR. Effect of limited hydrolysis of sunflower protein on the interactions with polysaccharides in foams. Food Hydrocolloid. 2005;19:361-9. https://doi.org/10.1016/j.foodhyd.2004.10.002

15. Karayannidou A, Makri E, Papalamprou E, Doxastakis G, Vaintraub I, Lapteva N, Articov G. Limited proteolysis as a tool for the improvement of the functionality of sunflower (Helianthus annus L.) protein isolates produced by seeds or industrial by-products (solvent cake). Food Chem. 2007;104: 1728-33. https://doi.org/10.1016/j.foodchem.2006.10.051

16. Bautista J, Corpas R, Cremades $\mathrm{O}$, Hernández-Pinzón I, Ramos R, Villanueva A, et al. Sunflower protein hydrolysates for dietary treatment of patients with liver failure. J Am Oil Chem Soc. 2000;77:121-6. https://doi.org/10.1007/s11746-000-0020-x

17. Heck T, Faccio G, Richter M, Thöny-Meyer L. Enzyme-catalyzed protein crosslinking. Appl Microbiol Biotechnol. 2013; 97:461-75.

https://doi.org/10.1007/s00253-012-4569-z

18. Kieliszek M, Misiewicz A. Microbial transglutaminase and its application in the food industry. A review. Folia Microbiol. 2014;59:241-50. https://doi.org/10.1007/s12223-013-0287-x

19. Dube M, Schäfer $C$, Neidhart $S$, Carle R. Texturisation and modification of vegetable proteins for food applications using microbial transglutaminase. Eur Food Res Technol. 2007; 225:287-99.

https://doi.org/10.1007/s00217-006-0401-2

20. Schäfer C, Zacherl C, Engel KH, Neidhart S, Carle R. Comparative study of gelation and cross-link formation during enzymatic texturisation of leguminous proteins. Innov Food Sci Emerg Technol. 2007;8:269-78.

https://doi.org/10.1016/j.ifset.2007.01.005

21. Ivanova P, Kalaydzhiev H, Chalova V, Koleva L. Influence of proteolysis on transglutaminase modification of sunflower protein isolates. Scientific Works of University of Food Technologies. 2015;62:321-6 (in Bulgarian).

22. Ivanova $\mathrm{P}$, Chalova V, Koleva L, Pishtiyski I, PerifanovaNemska M. Optimization of protein extraction from sunflower meal produced in Bulgaria. Bulg J Agric Sci. 2012;18: 153-60.

23. Kato A, Wada T, Kobayashi K, Seguro K, Motoki M. Ovomucin-food protein conjugates prepared through the transglutaminase reaction. Agric Biol Chem. 1991;55:1027-31. https://doi.org/10.1080/00021369.1991.10870722

24. Navarrete del Toro MA, García-Carreño FL. Evaluation of the progress of protein hydrolysis. Curr Protoc Food Analyt Chem. 2002; B2.2.1-14. https://doi.org/10.1002/0471142913.fac0202s10

25. Tomov T, Rachovski G, Kostadinova S, Manolov I. Handbook of agrochemistry. Plovdiv, Bulgaria: Academic Publisher of Agricultural University-Plovdiv; 2009.

26. AACC method 46-15. Crude protein -5-minute biuret method for wheat and other grains. St. Paul, MN, USA: American Association of Cereal Chemists International (AACCI); 1999.

27. Sze-Tao KWC, Sathe SK. Functional properties and in vitro digestibility of almond (Prunus dulcis L.) protein isolate. Food Chem. 2000;69:153-60.

https://doi.org/10.1016/S0308-8146(99)00244-7

28. Ivanova P, Chalova V, Koleva L. Functional properties of proteins isolated from industrially produced sunflower meal. Int J Food Studies. 2014;3:203-12. https://doi.org/10.7455/ijfs/3.2.2014.a6

29. Neto VQ, Narain N, Silva JB, Bora PS. Functional properties of raw and heat processed cashew nut (Anacardium occidentale L.) kernel protein isolates. Nahrung. 2001;45:258-62. https://doi.org/10.1002/1521-3803(20010801)45:4<258::AIDFOOD258>3.0.CO;2-3

30. Kato Y, Aoki T, Kato N, Nakamura R, Matsuda T. Modification of ovalbumin with glucose 6-phosphate by amino-carbonyl reaction. Improvement of protein heat stability and emulsifying activity. J Agric Food Chem. 1995;43:301-5. https://doi.org/10.1021/jf00050a007

31. Zayas JF. Solubility of proteins. In: Zayas JF, editor. Functionality of proteins in food. Berlin, Germany: Springer-Verlag; 1997. p. 6-75. https://doi.org/10.1007/978-3-642-59116-7

32. Ivanova P, Chalova V, Koleva L, Pishtiyski I. Amino acid composition and solubility of proteins isolated from sun- 
flower meal produced in Bulgaria. Int Food Res J. 2013;20: 2995-3000.

33. Burstin J, Gallardo K, Mir RR, Varshney RK, Duc G. Improving protein content and nutrition quality. In: Pratap A, Kumar J, editors. Biology and breeding of food legumes. Wallingford, UK: CAB International; 2011. p. 314-28. https://doi.org/10.1079/9781845937669.0000

34. Walsh DJ, Cleary D, McCarthy E, Murphy S, FitzGerald RJ Modification of the nitrogen solubility properties of soy protein isolate following proteolysis and transglutaminase cross-linking. Food Res Int. 2003;36:677-83. https://doi.org/10.1016/S0963-9969(03)00017-6

35. Flanagan J, FitzGerald RJ. Physicochemical and nitrogen solubility properties of Bacillus proteinase hydrolysates of sodium caseinate incubated with transglutaminase pre- and post-hydrolysis. J Agric Food Chem. 2002;50:5429-36. https://doi.org/10.1021/jf011632n

36. Babiker EFE, Fujisawa N, Matsudomi N, Kato A. Improvement in the functional properties of gluten by protease digestion or acid hydrolysis followed by microbial transglutaminase treatment. J Agric Food Chem. 1996;44:3746-50. https://doi.org/10.1021/jf960302d

37. Hassan AB, Osman GA, Babiker EE. Effect of chymotrypsin digestion followed by polysaccharide conjugation or transglutaminase treatment on functional properties of millet proteins. Food Chem. 2007;102:257-62. https://doi.org/10.1016/j.foodchem.2006.04.043

38. González-Pérez S, Vereijken JM, Merck KB, van Koningsveld GA, Gruppen H, Voragen AGJ. Conformational states of sunflower (Helianthus annuus) helianthinin: effect of heat and pH. J Agric Food Chem. 2004;52:6770-8. https://doi.org/10.1021/jf049612j

39. Babiker EE. Effect of transglutaminase treatment on the functional properties of native and chymotrypsin-digested soy protein. Food Chem. 2000;70:139-45. https://doi.org/10.1016/S0308-8146(99)00231-9

40. Flanagan J, FitzGerald RJ. Functional properties of Bacillus proteinase hydrolysates of sodium caseinate incubated with transglutaminase pre- and post-hydrolysis. Int Dairy J. 2003; 13:135-43. https://doi.org/10.1016/S0958-6946(02)00149-8

41. Claver IP, Zhou H. Enzymatic hydrolysis of defatted wheat germ by proteases and the effect on the functional properties of resulting protein hydrolysates. J Food Biochem. 2005;29: 13-26. https://doi.org/10.1111/j.1745-4514.2005.00004.x

42. Kong X, Zhou H, Qian H. Enzymatic preparation and functional properties of wheat gluten hydrolysates. Food Chem. 2007;101:615-20.

https://doi.org/10.1016/j.foodchem.2006.01.057

43. Wouters AGB, Rombouts I, Legein M, Fierens E, Brijs K, Blecker C, Delcour JA. Air-water interfacial properties of enzymatic wheat gluten hydrolyzates determine their foaming behavior. Food Hydrocolloid. 2016;55:155-62. https://doi.org/10.1016/j.foodhyd.2015.11.017

44. Guan X, Yao H, Chen Z, Shan L, Zhang M. Some functional properties of oat bran protein concentrate modified by trypsin. Food Chem. 2007;101:163-70.

https://doi.org/10.1016/j.foodchem.2006.01.011
45. Larré C, Mulder W, Sánchez-Vioque R, Lazko J, Bérot S, Guéguen J, Popineau $Y$. Characterisation and foaming properties of hydrolysates derived from rapeseed isolate. Colloids Surf B Biointerfaces. 2006;49:40-8. https://doi.org/10.1016/j.colsurfb.2006.02.009

46. Jung KH, Choi YC, Chun JY, Min SG, Hong GP. Effects of concentration and reaction time of trypsin, pepsin, and chymotrypsin on the hydrolysis efficiency of porcine placenta. Korean J Food Sci An. 2014;34:151-7. https://doi.org/10.5851/kosfa.2014.34.2.151

47. Krzan M, Caps H, Vandewalle N. High stability of the bovine serum albumine foams evidenced in Hele-Shaw cell. Colloids Surf A Physicochem Eng Asp. 2013;438:112-8. https://doi.org/10.1016/j.colsurfa.2013.01.012

48. Chobert JM, Bertrand-Harb C, Nicolas MG. Solubility and emulsifying properties of caseins and whey proteins modified enzymically by trypsin. J Agric Food Chem. 1988;36:883-92. https://doi.org/10.1021/jf00083a002

49. Gbogouri GA, Linder M, Fanni J, Parmentier M. Influence of hydrolysis degree on the functional properties of salmon by-products hydrolysates. J Food Sci. 2004;69:C615-22. https://doi.org/10.1111/j.1365-2621.2004.tb09909.x

50. Ahmed AR, Ramanatham G. Effect of natural fermentation on the functional properties of protein-enriched composite flour. J Food Sci. 1988;53:218-21. https://doi.org/10.1111/j.1365-2621.1988.tb10213.x

51. Subba Rau BH, Srinivasan KS. Enzymatic modification of groundnut flour (by papain/protease) and its effect on functional properties. LWT - Food Sci Technol. 1988;21:126-30.

52. Hu X, Ren J, Zhao M, Cui C, He P. Emulsifying properties of the transglutaminase-treated crosslinked product between peanut protein and fish (Decapterus maruadsi) protein hydrolysates. J Sci Food Agric. 2011;91:578-85. https://doi.org/10.1002/jsfa.4229

53. Ryan $\mathrm{KN}$, Zhong $\mathrm{Q}$, Foegeding EA. Use of whey protein soluble agregates for thermal stability - a hypothesis paper. J Food Sci. 2013;78:R1105-15. https://doi.org/10.1111/1750-3841.12207

54. Strub C, Alies C, Lougarre A, Ladurantie C, Czaplicki J, Fournier D. Mutation of exposed hydrophobic amino acids to arginine to increase protein stability. BMC Biochem. 2004;5:9-14. https://doi.org/10.1186/1471-2091-5-9

55. Ali NA, Ahmed SH, Mohamed EA, Mohamed Ahmed IA, Babiker EE. Effect of transglutaminase cross linking on the functional properties as a function of $\mathrm{NaCl}$ concentration of legumes protein isolate. Int J Biol Biomol Agric Food Biotechnol Eng. 2010;4:27-32.

56. Siu NC, Ma CY, Mock WY, Mine Y. Functional properties of oat globulin modified by a calcium-independent microbial transglutaminase. J Agric Food Chem. 2002;50:2666-72. https://doi.org/10.1021/jf011163p

57. O'Sullivan MM, Kelly AL, Fox PF. Effect of transglutaminase on the heat stability of milk: a possible mechanism. J Dairy Sci. 2002;85:1-7. https://doi.org/10.3168/jds.S0022-0302(02)74045-9

58. Hoffmann MAM, van Mil PJJM. Heat-induced aggregation of $\beta$-lactoglobulin: role of the free thiol group and disulfide bonds. J Agric Food Chem. 1997;45:2942-8. https://doi.org/10.1021/jf960789q 